\title{
A cut-and-closure origin for englacial conduits in uncrevassed regions of polythermal glaciers
}

\author{
J.D. GULLEY, ${ }^{1,2}$ D.I. BENN, ${ }^{2,3}$ D. MÜLLER, ${ }^{2,4}$ A. LUCKMAN ${ }^{5}$ \\ ${ }^{1}$ Department of Geological Sciences, University of Florida, 241 Williamson Hall, PO Box 112120, Gainesville, \\ Florida 32611, USA \\ ${ }^{2}$ Department of Geology, The University Centre in Svalbard (UNIS), Box 156, NO-9171 Longyearbyen, Norway \\ E-mail: doug.benn@unis.no \\ ${ }^{3}$ School of Geography and Geosciences, University of St Andrews, St Andrews KY16 9AL, UK \\ ${ }^{4}$ Technische Universität Braunschweig, Pockelsstrasse 4, D-38106 Braunschweig, Germany \\ ${ }^{5}$ Glaciology Group, School of the Environment and Society, Swansea University, Singleton Park, Swansea SA2 8PP, UK
}

\begin{abstract}
On uncrevassed regions of polythermal glaciers, englacial conduits can form by incision of supraglacial stream channels followed by roof closure. The origin and evolution of examples in Longyearbreen, Svalbard, and Khumbu Glacier, Nepal, were determined by speleological survey. The development of perennial incised channels requires that incision is significantly faster than glacier surface ablation, and thus will be favoured by high meltwater discharges in combination with cool climatic conditions or thick debris cover. Incised canyons can become blocked by drifted winter snow, refrozen meltwater, ice rafting from non-local sources (allochthonous breccias) and roof collapses (autochthonous breccias). Conduit closure can also occur in response to ice creep, particularly at depth. Following isolation from the surface, englacial conduits continue to evolve by vadose incision down to local base level. In the case of Longyearbreen, incision allowed the channel to reach the glacier bed, but on Khumbu Glacier deep incision is prevented because an effectively impermeable terminal moraine provides a high base level for the glacier drainage system. During our period of observations, deeper parts of the Longyearbreen conduit became blocked by a combination of ice accumulation and creep, causing the stream course to be re-routed to higher levels. On that glacier, incision, blockage and upward re-routing are cyclic. We conclude that 'cut and closure' is the dominant mechanism of englacial conduit formation on uncrevassed regions of polythermal glaciers.
\end{abstract}

\section{INTRODUCTION}

The realization that surface-derived meltwater can modulate basal motion of high-latitude glaciers and ice sheets has led to increased interest in mechanisms of englacial drainage through polythermal glaciers (Zwally and others, 2002; Boon and Sharp, 2003; Copland and others, 2003). How englacial drainage systems form and evolve, and under what circumstances they can reach glacier beds, are important but poorly understood issues. The 'classical' model of englacial drainage development (Shreve, 1972) is based on the idea that arborescent systems of conduits evolve from intergranular veins by exploiting the primary permeability of ice, analogous to Darcian flow in a homogeneous, isotropic medium. Individual conduits are predicted to trend normal to equipotential surfaces determined by elevation, ice overburden pressure and conduit radius. In cold ice, however, the water-filled vein networks invoked to act as conduit nuclei are absent, so this model cannot explain the evolution of drainage networks that traverse cold regions of glaciers (Hodgkins, 1997, Stuart and others, 2003). Moreover, some reported characteristics of englacial drainages in polythermal glaciers are incompatible with the 'classical' model. For example, passages have been observed to dip more steeply (Pulina, 1984; Holmlund, 1988; Pulina and Rehák, 1991) or less steeply (Pulina, 1984; Arcone and Yankielun, 2000; Vatne, 2001; Stuart and others, 2003; Vatne and Refsnes, 2003; Gulley and Benn, 2007) than predicted, or to have a fracture-like geometry (Fountain and others, 2005).
A number of alternative models have been proposed for the development of englacial drainages. Fountain and Walder (1998) proposed that conduits can form by incision of free-surface streams flowing along the bottom of crevasses. According to this model, ice creep will pinch off the crevasse above the incising stream and the conduit may, over many melt seasons, reach the glacier bed. Vatne (2001) described an englacial conduit in Austre Brøggerbreen, Svalbard, which appears to have formed by incision of a stream channel followed by creep closure. The role of surface crevasses in controlling the location of this conduit, however, is not known. It has long been supposed that stress conditions in water-filled crevasses could allow fractures to propagate to the bed, initiating steep surface-to-bed moulins (e.g. Robin, 1974; Röthlisberger and Lang, 1987). Recently, theoretical analyses (Alley and others, 2005; Van der Veen, 2007), observations of surface drainage events (Boon and Sharp, 2003) and geophysical studies (Catania and others, 2008) indicate that this mechanism can rapidly route surface meltwater through cold ice, thus explaining the close association between surface melt events and accelerated basal motion. Finally, Gulley and Benn (2007) have shown that near-surface conduits can form along permeable englacial debris bands connecting areas with different hydraulic potential.

These multiple theories of englacial formation have been developed primarily through interpretations of proxy data, such as dye-tracing and geophysical measurements, or theoretical considerations, thus limiting understanding of the physical processes controlling their formation and 
distribution. Studies of conduit morphologies in limestone have greatly facilitated interpretation of proxy data and refinement of numerical models (White, 1988), so morphological studies of englacial conduits should also facilitate glaciohydrological modeling efforts. However, detailed maps of englacial conduits are virtually non-existent. Consequently, we have created detailed, three-dimensional (3-D) maps of englacial conduits in cold ice in Longyearbreen, Svalbard, Norway, and Khumbu Glacier, Nepal. These glaciers were chosen as representative of uncrevassed high-Arctic glaciers and high-altitude debris-covered glaciers, respectively, and were studied as part of a systematic survey of englacial conduits in a range of glaciological settings.

The conduits were entered and surveyed using standard speleological techniques modified for glacier caves (Dasher, 1997; Gulley and Benn, 2007). Maps and scale drawings of passages were rendered in situ, in plan, profile and crosssection view and include observations of glaciostructural and stratigraphic features exposed in passage walls, allowing the origin and evolution of the conduits to be reconstructed in detail. In addition, repeat visits to the caves allowed aspects of their evolution to be directly monitored. At Longyearbreen, rates of passage closure were determined during winter 2006/07 using pairs of stakes drilled into opposite tunnel walls, and floor incision rates in an adjacent subaerial reach of the drainage system were measured during summer 2006. A detailed account of measurement methods is given by Müller (2007).

\section{LONGYEARBREEN, SVALBARD}

\subsection{General description}

Longyearbreen $\left(78^{\circ} 11^{\prime} \mathrm{N}, 15^{\circ} 31^{\prime} \mathrm{E}\right)$ is $\sim 5 \mathrm{~km}$ long, and flows northward from a cirque accumulation basin (Fig. 1). Radioecho soundings and direct temperature measurements indicate that the glacier is predominantly below the pressure-melting point, except for a temperate surface layer in its upper reaches associated with refreezing of summer meltwater within the snowpack (Etzelmüller and others, 2000; Humlum and others, 2005). It is therefore a polythermal glacier of type $\mathrm{B}$ according to the classification of Blatter and Hutter (1991). The glacier appears to be everywhere frozen to its bed, and the observed ice-flow velocities of $1-4 \mathrm{~m} \mathrm{a}^{-1}$ are entirely attributable to ice creep (Etzelmüller and others, 2000). The uncrevassed glacier surface is mostly debris-free, except for inactive ice-cored moraines in the terminal zone and along both flanks of the glacier. Mass-balance measurements conducted from 1977 to 1992 showed that Longyearbreen had an average mean annual specific mass balance of $-0.55 \mathrm{ma}^{-1}$ at that time (Hagen and others, 2003), and observations on nearby glaciers suggest that the mass balance has probably been even more negative in recent years, with net mass loss occurring over the entire glacier surface (Neumann, 2006). During the ablation season, numerous meltwater channels develop on the surface of Longyearbreen, with the largest forming in the hollows between the main body of the glacier and the icecored lateral moraines. The lateral drainage systems on both sides of the glacier have supraglacial and englacial reaches.

The focus of this study is the larger and better-developed western lateral drainage system. In late August 2006, the upper part of the system consisted of an incised supraglacial

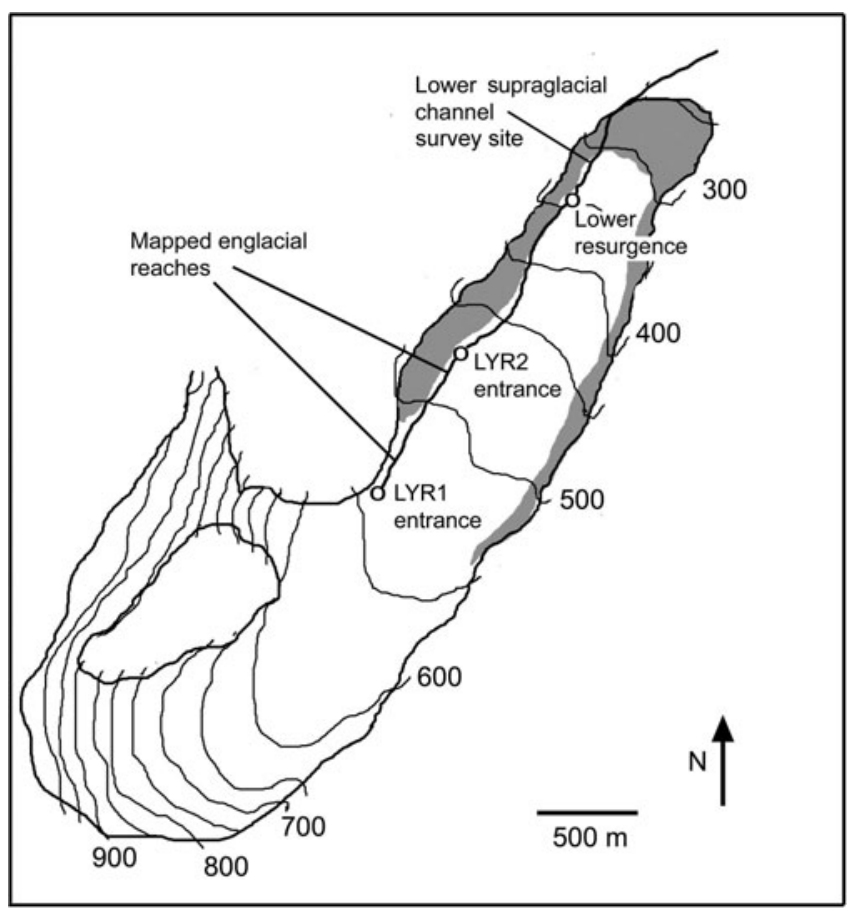

Fig. 1. Map of Longyearbreen, showing western drainage system and the location of cave entrances. Ice-cored moraine is indicated in grey tone.

channel which was intermittently roofed by old snow. Below an elevation of $486 \mathrm{~m}$, the snow roof became more continuous, and could be traced as a meandering line across the glacier surface for $262 \mathrm{~m}$ until it became buried by debris cover at the foot of the ice-cored moraine (Fig. 2a). A similar meandering snow roof, with occasional holes, was also visible adjacent to the ice-cored moraine at $\sim 423 \mathrm{~m}$ a.s.l. Meltwater re-emerged from the glacier at a resurgence below the ice-cored moraine at $357 \mathrm{~m}$ a.s.l., and thereafter followed an incised supraglacial channel to the glacier terminus. The englacial reach has been explored on several occasions during the past decade. Repeated surveys by Hansen (2001) between 1998 and 2001 showed that the englacial part of the system consisted of a meandering passage with long gently sloping sections interspersed with short steep steps. Passage morphology changed from year to year as a result of vertical incision and horizontal meander migration. Vertical incision rates were in the region of 1.2$5 \mathrm{~m} \mathrm{a}^{-1}$, higher than net glacier surface ablation rates of $\sim 1 \mathrm{~m} \mathrm{a}^{-1}$ at this location. Between 2001 and 2003, part of the passage floor was incised into the glacier bed, which consisted of angular scree-like regolith $\sim 35 \mathrm{~m}$ below the glacier surface (Fig. 2b). In situ plant remains recovered from the ice-bed interface show that no basal motion has occurred at this site since the glacier advanced over it 1100 years ago (Humlum and others, 2005). Hansen (2001) concluded that the englacial/subglacial part of the western drainage system had evolved from a deeply incised supraglacial channel, following creep closure of higher, abandoned levels. To investigate the origin of the western drainage system in more detail, we conducted studies of supraglacial and englacial reaches during summer 2006 and winter 2006/07. Studies of the supraglacial parts of the system focused on short-term rates and patterns of incision, which are difficult to measure in englacial parts of the 

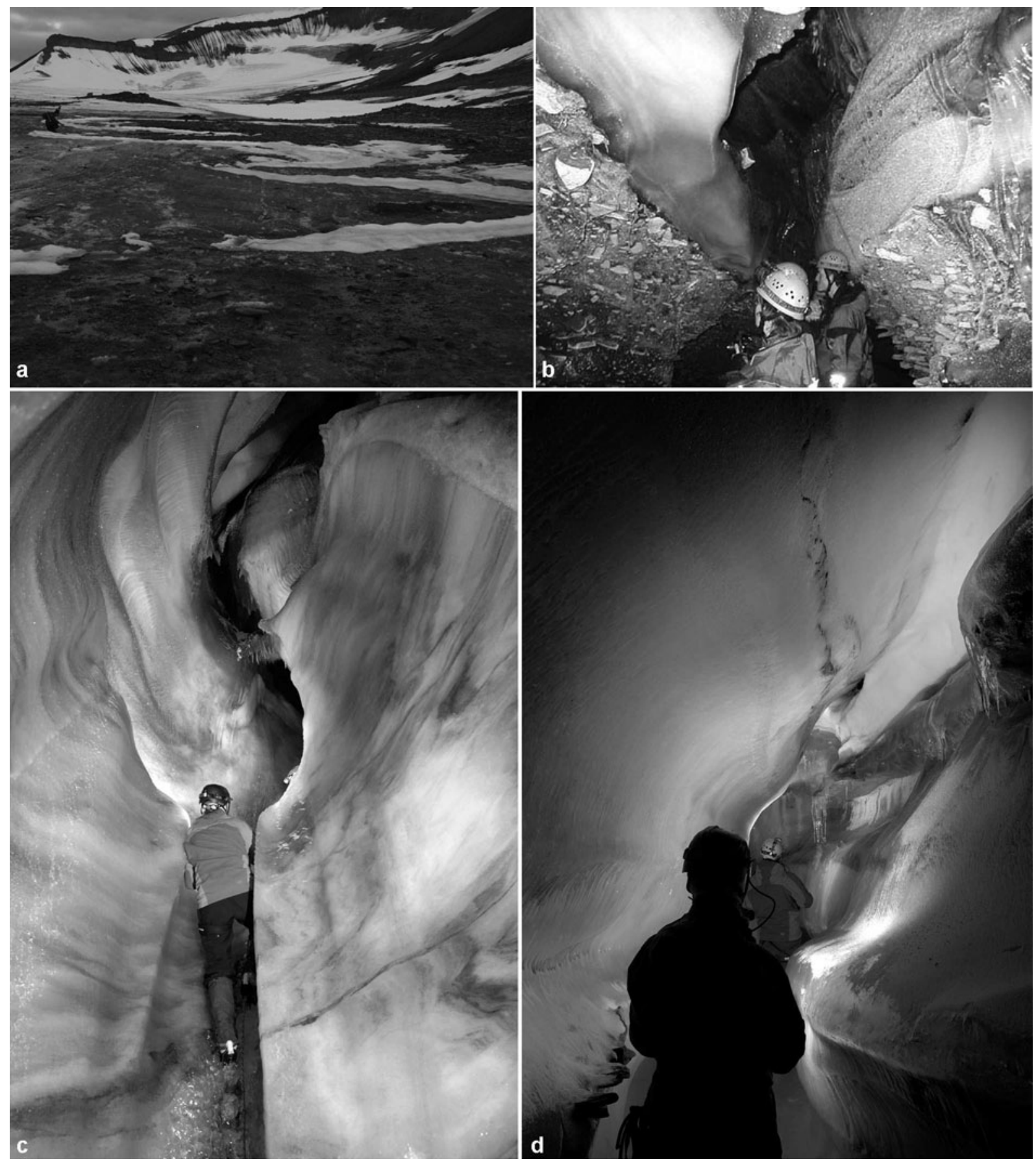

Fig. 2. (a) Meandering snow plug at the surface of Longyearbreen above LYR1. (b) Subglacial section of the western drainage system, March 2001. This section of the bed is located below the lower end of LYR2, and consists of stony regolith capped by in situ soil and vegetation. (Photo: Ole Humlum.) (c) Nickpoint in the unsurveyed downstream section of LYR1. (d) A plug of snow, aufeis or névé was traceable along the apex of the canyon passage for the entire surveyed length of LYR1.

system for safety reasons. Work in the englacial parts of the system focused on longer-term patterns of channel incision and migration, and tunnel closure mechanisms. Rates of tunnel wall closure over the period September 2006 to January 2007 were determined from repeated measurements of pairs of stakes emplaced in the passage walls.

\subsection{The lower supraglacial channel}

The channel consisted of gently sloping sections interspersed with nickpoints and had an overall gradient of 0.13 . Rates of channel incision and lateral migration, and concurrent measurements of ablation of the ice surface on either side of the channel, were determined at three cross-sections in a $12 \mathrm{~m}$ channel reach at $332 \mathrm{~m}$ a.s.I. between Julian day (JD) 209 and JD 251 (28 July to 8 September) (Table 1; Müller, 2007). Measurements began when the snowline retreated past the site, and ended at the end of the ablation season.

We recorded large spatio-temporal variations in incision rates (Table 1 ). Well-above-average incision rates recorded at sites 1 and 2 occurred when a nickpoint migrated through the cross-sections. Nickpoint migration rate was 35$47 \mathrm{~cm} \mathrm{~d}^{-1}$, while channel floor incision rates of $4.1 \mathrm{~cm} \mathrm{~d}^{-1}$ were measured at site 3 . Total incision of the channel floor averaged $4.05 \mathrm{~m}$ compared with glacier surface lowering of 
$1.01 \mathrm{~m}$, so that the channel floor was $\sim 3 \mathrm{~m}$ deeper relative to the glacier surface at the end of the period than at the beginning.

\subsection{Englacial passages}

The englacial portion of the western drainage system was entered at two localities (LYR1, LYR2; Fig. 1) in October 2006. The upper reach (LYR1) was surveyed down-glacier for $332 \mathrm{~m}$. The passage was followed down a series of nickpoints (Fig. 2c) for an additional $\sim 600-700 \mathrm{~m}$ until further progress was blocked by deep pools of water. The passage was observed to continue, however. The lower reach (LYR2) was surveyed for $570 \mathrm{~m}$ up-glacier and $59.3 \mathrm{~m}$ down-glacier. Including meander bypasses, $745 \mathrm{~m}$ of passage were surveyed in LYR2. Up-glacier progress was terminated by a deep pool of water, probably a few meters short of LYR1. Downstream, LYR2 terminated in a frozen pool with no above-water continuation.

Both reaches were meandering canyons with sinuosities of 2.17 (LYR1) and 2.11 (LYR2) (Fig. 3a and b: a legend for these and all subsequent maps is provided in Fig. 4). Unless otherwise noted, all measurements of gradient and sinuosity apply to the entire surveyed reach of conduits as measured along the thalweg. Meander cut-offs occurred in several places, sometimes perched several meters above the main passage. Average passage gradient was 0.03 in both cases, but most of the elevation change is attributed to nickpoints.

LYR1 has a canyon morphology with sub-parallel walls, which are either vertical or tilted up towards the centre of meander bends where they taper into snow or névé. Fresh snowdrifts or icings partially or completely blocked the canyon at several locations (e.g. between A16 and A17; Fig 3a).

Passage morphology in LYR2 is more variable, and can be classified into four main types: (1) plugged canyons, (2) sutured canyons, (3) horizontal slots and (4) tubular passages. The plugged canyon morphology (Fig. 2d) is similar to that in LYR1. Plugged canyons are defined as relatively narrow, tall passages roofed by snow or aufeis infill. In LYR2 this occurs mainly down-glacier of the entrance (F5-A2, Fig. 3b), where the passage reaches a maximum of $11 \mathrm{~m}$ in height at the downstream end of a series of nickpoints.

The term sutured canyon is introduced to refer to canyons with walls brought into contact by ice flow. They do not have infillings of snow or aufeis, and the passage walls taper into an angular ceiling. Sutured canyons are common up-glacier of A29 (Fig. 3b). Areas of contact (or sutures) can occur part-way up canyons, where bulges in opposing walls are brought together, or form the passage roof or floor (e.g. Fig 3b (stations A29, A30, A31, A48) and Fig 5a). In several places, sutures separate upper and lower levels of the passage (e.g. between A40 and A50 in Fig. 3b) and have probably isolated numerous inaccessible voids within the glacier. Creep closure has also folded ice floors and deformed icicles at several locations. Passage closure rates were determined at A29 (Fig. 3b) (12.8 m ice overburden) by measuring the change in distance between three pairs of stakes emplaced in opposite walls between 20 September 2006 and 18 January 2007. During this period, the walls converged by $4.2-4.8 \mathrm{~cm}$, an average rate of $0.35-0.40 \mathrm{~mm} \mathrm{~d}^{-1}$. Similar measurements made at sections A22 (Fig. 3b) (8.0 m ice overburden) and F3 (9.1 $\mathrm{m}$ ice overburden) indicated stable passage dimensions over the same period.
Table 1. Lowering rates in the Longyearbreen supraglacial channel and ablation rates for the adjacent glacier surface. Units are $\mathrm{cm} \mathrm{d}^{-1}$

$$
\text { Channel lowering Surface ablation }
$$

Mean Max. Std dev. Mean Max. Std dev.

\begin{tabular}{lrrrrrr}
\hline$J D$ 209-251 & & & & & & \\
Cross-section 1 & 10.4 & 32.9 & 9.9 & 2.2 & 5.7 & 1.2 \\
Cross-section 2 & 13.1 & 33.1 & 5.6 & 2.6 & 4.9 & 1.4 \\
Cross-section 3 & 4.1 & 8.7 & 2.5 & 2.2 & 7.2 & 1.5 \\
All sites & 9.2 & & & 2.3 & & \\
& & & & & & \\
$J D$ 209-230 & & & & & & \\
Cross-section 1 & 17.9 & 32.9 & 1.3 & 3.0 & 5.7 & 1.3 \\
Cross-section 2 & 14.5 & 33.1 & 7.6 & 3.5 & 4.9 & 1.6 \\
Cross-section 3 & 6.1 & 8.7 & 2.3 & 3.4 & 7.2 & 1.5 \\
& & & & & & \\
$J D$ 231-251 & & & & & & \\
Cross-section 1 & 2.8 & 2.5 & 0.4 & 1.5 & 2.2 & 0.4 \\
Cross-section 2 & 11.7 & 12.2 & 1.7 & 1.8 & 1.9 & 0.3 \\
Cross-section 3 & 2.3 & 2.7 & 0.7 & 1.2 & 1.3 & 0.1 \\
\hline
\end{tabular}

Horizontal slots are wide with very low roofs, and occur in several places upstream of A32 (Fig. 5b). They are commonly separated from upper canyon passage segments by sutures. Horizontal slots tend to become progressively lower during the winter, through a combination of aufeis accumulation and creep closure.

The tubular passage sections in LYR2 are roughly elliptical in cross-section, but tend to be somewhat irregular. They occur only in a restricted area, a few tens of meters upstream from the entrance (A4-A7, Fig. 3a). Morphologically, this passage type is a hybrid between the circular passage cross-sections that form under pipe-full (phreatic) conditions and the incised canyon morphology of vadose streams (Fig. 5c; Ford and Williams, 2007; Gulley and Benn, 2007).

Although other workers had previously reported observing the glacier bed in past manifestations of LYR2, we did not reach the bed during 2006/07. In the vicinity of the former subglacial reach, the floor was only $15 \mathrm{~m}$ below the surface and about $15 \mathrm{~m}$ above the glacier bed. This means that the same conduit was at least $15 \mathrm{~m}$ higher in the ice than it was in 2003 (Humlum and others, 2005).

Conduit blockage and discharge re-routing occurred at the lower end of LYR2 during our study. In October 2006, LYR2 terminated downstream in a frozen pool. Soundings taken through the ice revealed the pool was $8 \mathrm{~m}$ deep. This pool was not present in the winter of 2005/06, at which time a nickpoint led to a lower passage which rapidly diminished to a low horizontal slot.

In July 2007, LYR2 back-flooded and discharged from the roof of F5 to a supraglacial channel (Fig. 5d). During this event there was no discharge issuing from the LYR3 resurgence.

\subsection{Interpretation}

The incised canyon morphology, stepped long profile, and snow and névé plugged roofs indicate LYR1 originated as an incised supraglacial channel and became isolated from the surface. Conduit deepening occurs each summer because incision rates outpace surface ablation. Incision is dominated by nickpoint migration. Nickpoint migration is faster 


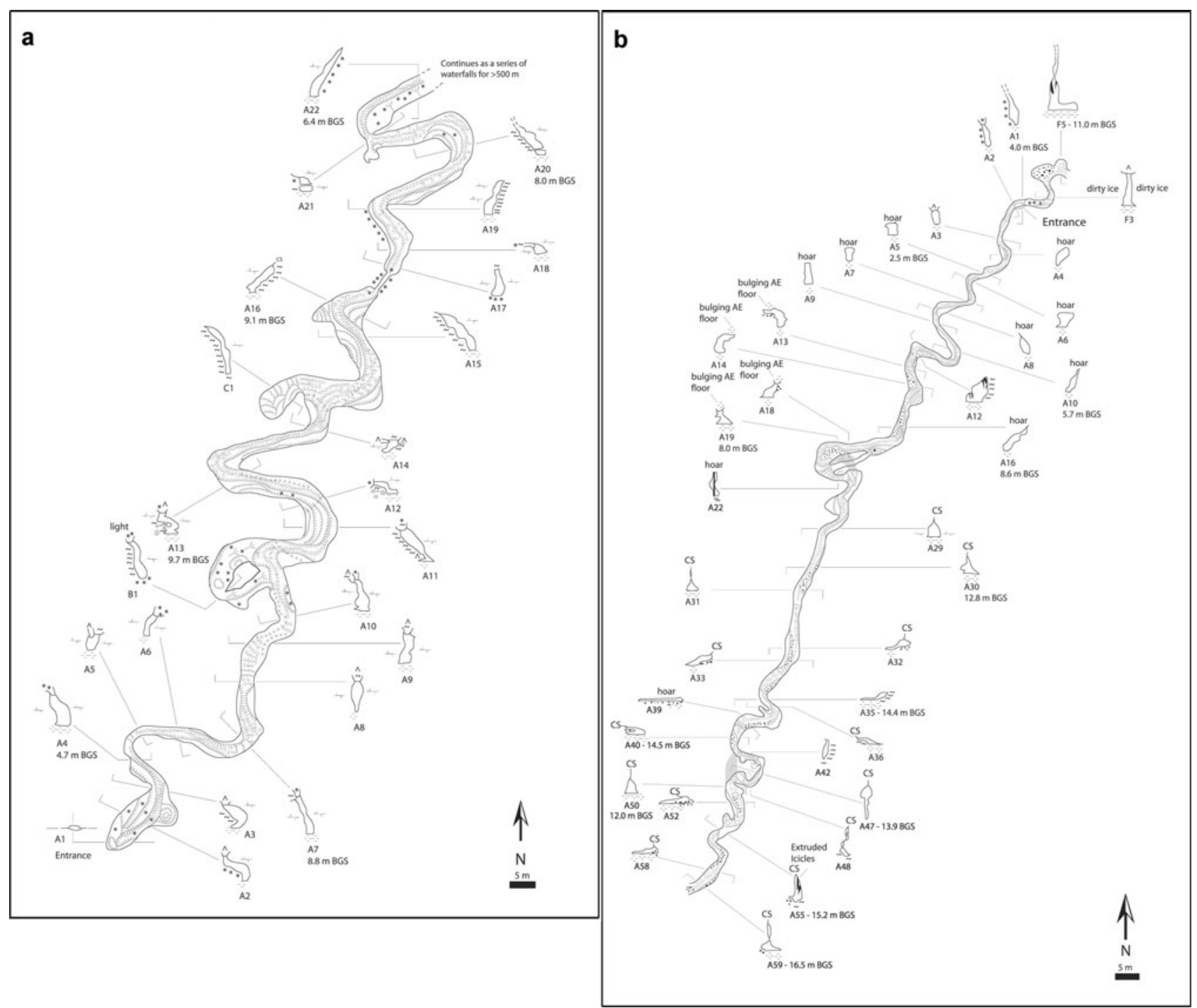

Fig. 3. Plan views of conduits surveyed on Longyearbreen, October 2006: (a) LYR1; (b) LYR2. Depth below glacier surface (BGS) is indicated at approximately every fifth station.

than down-cutting because viscous dissipation provides the energy for melting and is directly proportional to discharge and channel slope (Fountain and Walder, 1998). More steeply sloping sections of the channel floor, therefore, will incise more rapidly than gently sloping reaches. Large nickpoints will tend to migrate more rapidly than small ones, leading to 'capture' and the rapid evolution of sloping reaches into series of waterfalls and plunge pools (cf. Knighton, 1985; Piccini and others, 2000).

Passage roof closure results from three processes: plugging by snow and ice, burial by debris derived from the icecored moraine, and creep closure at greater depths. Plugging occurs when snow bridges fail to completely melt during the ablation season. In the following autumn the wet snow bridges refreeze, increasing their density and encouraging their survival in subsequent years. Debris flows from the ice-cored moraine can cover the snow bridges, further encouraging their survival by reducing surface melt rates. Sutured canyons are interpreted as incised passages in which upper levels have closed by ice creep. Measured wall convergence rates show that ice creep can be an important mechanism of passage closure at depths greater than $\sim 12 \mathrm{~m}$. Low, wide passages (horizontal slots) are created in the deepest parts of the system by a combination of lateral channel migration and the closure of relict higher levels by creep and secondary ice accumulation.

The tubular sections (Fig. $5 \mathrm{c}$ and d) appear to reflect passage re-enlargement by wall melting. Constricted conduit cross-sections encourage transient phreatic (pipe-full) conditions during periods of high meltwater discharge, and we infer that consequent passage enlargement creates hybrids of phreatic and vadose cross-sections (cf. Ford and Williams, 1989; Gulley and Benn, 2007). Transient phreatic conditions are a common hydrological condition in limestone karst and are called epiphreatic, or flood phreatic (White, 1988).

Winter closure of passages by ice build-up and/or ice creep forces conduits to find an alternative outlet: most commonly a breach in the passage ceiling. Blockage and drainage re-routing occurred at the lower end of LYR2 during winter 2006/07. The englacial channel became blocked when the deep horizontal slot observed in the 2005/06 winter season was occluded by waterfall ice originating from a hole in the ceiling. Meltwater filled the lower part of LYR2 up to the level of the lowest outflow point onto the glacier surface (Fig 3c, between A1 and F3), $14 \mathrm{~m}$ above the level of the frozen pool. From this point, the 
stream followed the glacier surface, bypassing $\sim 50 \mathrm{~m}$ of former englacial passage. This resurgence (Fig 3c, between A1 and F3) created a new local base level for the conduit upstream, which otherwise would have flooded back to A19. Flooding therefore created an epiphreatic loop from a formerly vadose passage. Previous epiphreatic conditions explain the tubular passage morphology between the entrance and A8 (Fig. 3b). Melting of the conduit ceiling at times of high discharge could initiate upward incision. This process, called paragenesis in limestone caves, will be assisted by bed-load armoring of the conduit floor when suspended sediments are deposited due to diminished sediment transport capacity under pipe-full conditions (White, 1988; Palmer, 2002). Downward incision is expected to occur at the resurgence at the same time that upward incision was occurring in the flooded conduit. Once downward incision lowers the water level in the conduit back to atmospheric levels, the conduit will incise downward into the ice as before.

\section{KHUMBU GLACIER, NEPAL HIMALAYA}

\subsection{General description}

Khumbu Glacier $\left(28^{\circ} 00^{\prime} \mathrm{N}, 86^{\circ} 51^{\prime} \mathrm{E}\right)$ is a $16 \mathrm{~km}$ long, debriscovered valley glacier in the upper Dudh Kosi catchment in Nepal, terminating at $\sim 4900$ m a.s.l. The main accumulation basin is in the Western Cwm to the south of Qomolangma (Mount Everest), from where ice flows via the Khumbu icefall to the ablation area. Below the icefall, debris cover increases in extent and thickness towards the terminus, where it is several meters thick. Measurements in shallow boreholes in the upper part of the ablation area indicate perennial cold ice in a surface layer $\sim 16 \mathrm{~m}$ thick, and temperate ice at greater depths (Mae, 1976). Furthermore, pronounced seasonal velocity variations in this area (Kodama and Mae, 1976; Seko and others, 1998; Nakawo and others, 1999) strongly suggest the existence of temperate basal ice beneath the icefall and upper ablation areas. Khumbu Glacier is therefore interpreted as polythermal, of type D in the Blatter and Hutter (1991) classification.

The ablation area of the glacier can be subdivided into two contrasting zones. The upper zone, above $\sim 5000 \mathrm{~m}$, has an average surface gradient of around $4^{\circ}$, and ice velocities of $20-40 \mathrm{~m} \mathrm{a}^{-1}$. In contrast, the lower zone has an average surface gradient of $<1^{\circ}$ and is stagnant, or nearly so, with velocities $<5 \mathrm{~m} \mathrm{a}^{-1}$. Uneven ablation of the debris-covered ice has produced highly irregular surfaces in both zones. Relative relief is highest in the lower zone, with mounds and ridges up to $50 \mathrm{~m}$ high separating topographic lows, many of which are occupied by supraglacial ponds (Iwata and others, 1980; Nakawo and others, 1999). In the upper zone, summer meltwater drains via several incised supraglacial streams that meander across the glacier surface (Fig. 6). These streams enter englacial conduits in the lower part of the upper zone, and drainage lower down the glacier is predominantly englacial until water re-emerges onto the glacier surface very close to the terminus (Iwata and others, 1980). Water leaves the glacier via a spillway over the terminal moraine, which acts as hydrological base level for the whole glacier system (cf. Gulley and Benn, 2007). Two englacial conduits, located at the down-glacier ends of relict and active supraglacial channels, respectively, were surveyed: $\mathrm{KH} 01$ in November 2005, and KHO2 in December 2006.

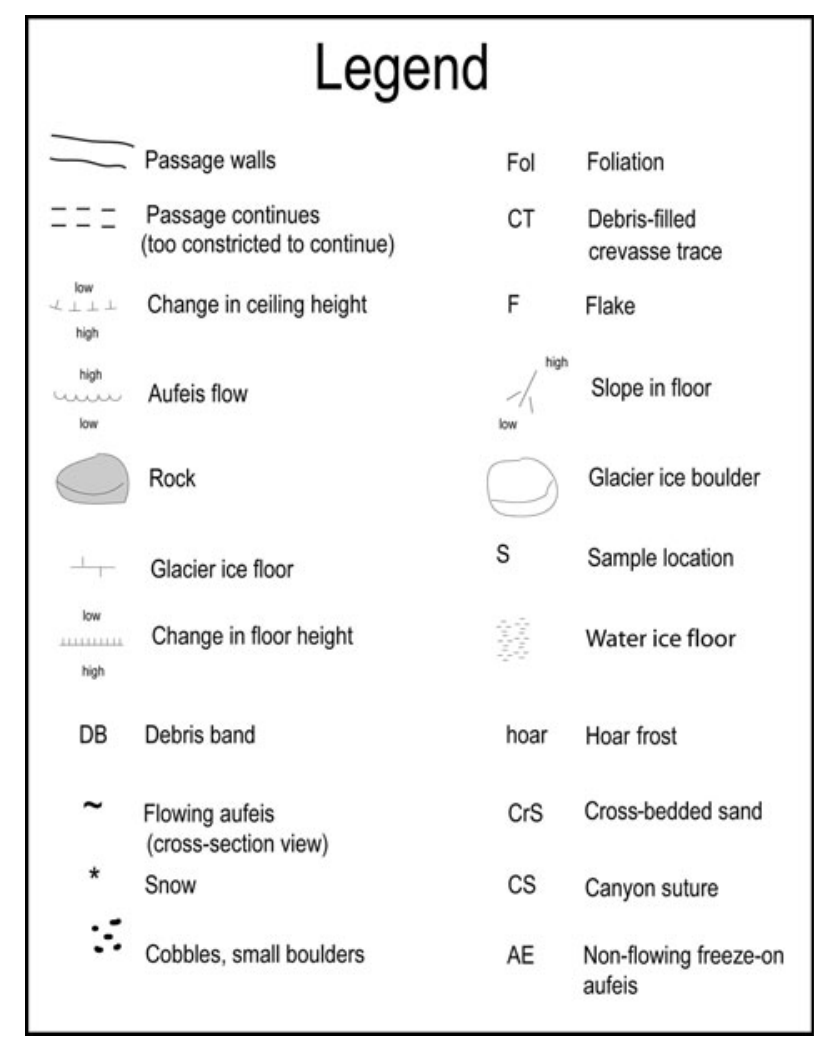

Fig. 4. Legend for conduit survey maps.

\subsection{KH01}

This englacial conduit was located near the western flank of the glacier $\left(27^{\circ} 59^{\prime} 5^{\prime \prime} \mathrm{N}, 86^{\circ} 10^{\prime} 16^{\prime \prime} \mathrm{E} ; 5083 \mathrm{~m}\right.$ a.s.I.), and consisted of two segments separated by a bouldery hollow in the glacier surface. The upper segment (KH01A) was a large, meandering canyon, fed at its upper (southeast) end by a meandering supraglacial channel originating below the Khumbu icefall. The lower segment (KH01B) was more constricted and was partially surveyed but not sketched, for safety reasons. KH01A formed a highly sinuous canyon (sinuosity 3.21) with an average gradient of 0.03 (Figs 7a and $\mathrm{b}$ and 8). Canyon walls tilted alternately to the left and right, up towards the inside of meander bends. There were no significant steps in the canyon, which was floored by a porous sub-horizontal mass of ice crystals at least $0.4 \mathrm{~m}$ deep, interpreted as an accumulation of frazil ice that masked the true floor morphology. Water was flowing beneath this ice accumulation, and exited at the downstream opening before disappearing beneath bouldery supraglacial debris. The canyon roof consisted of a band of partially ice-cemented debris and ice breccia perforated by windows to the glacier surface (Fig. 7c). The width of the band varied between 2 and $0.3 \mathrm{~m}$.

The upstream entrance of KH01B was extremely constricted and entry was gained by squeezing through a partially refrozen ice breccia. The passage continued as a horizontal slot $0.3-1 \mathrm{~m}$ high for $40 \mathrm{~m}$. Large semi-detached ice blocks, spalling flakes and ice breccia decorated the hanging wall. At a penetration of $56 \mathrm{~m}$, a short side passage extended north through the ice breccia and connected with the glacier surface. Downstream of the junction, the main passage was generally larger, and continued southwest as an inclined canyon for $120 \mathrm{~m}$ as the lowest-gradient (0.01) and straightest (sinuosity 1.17) passage in our sample set. 

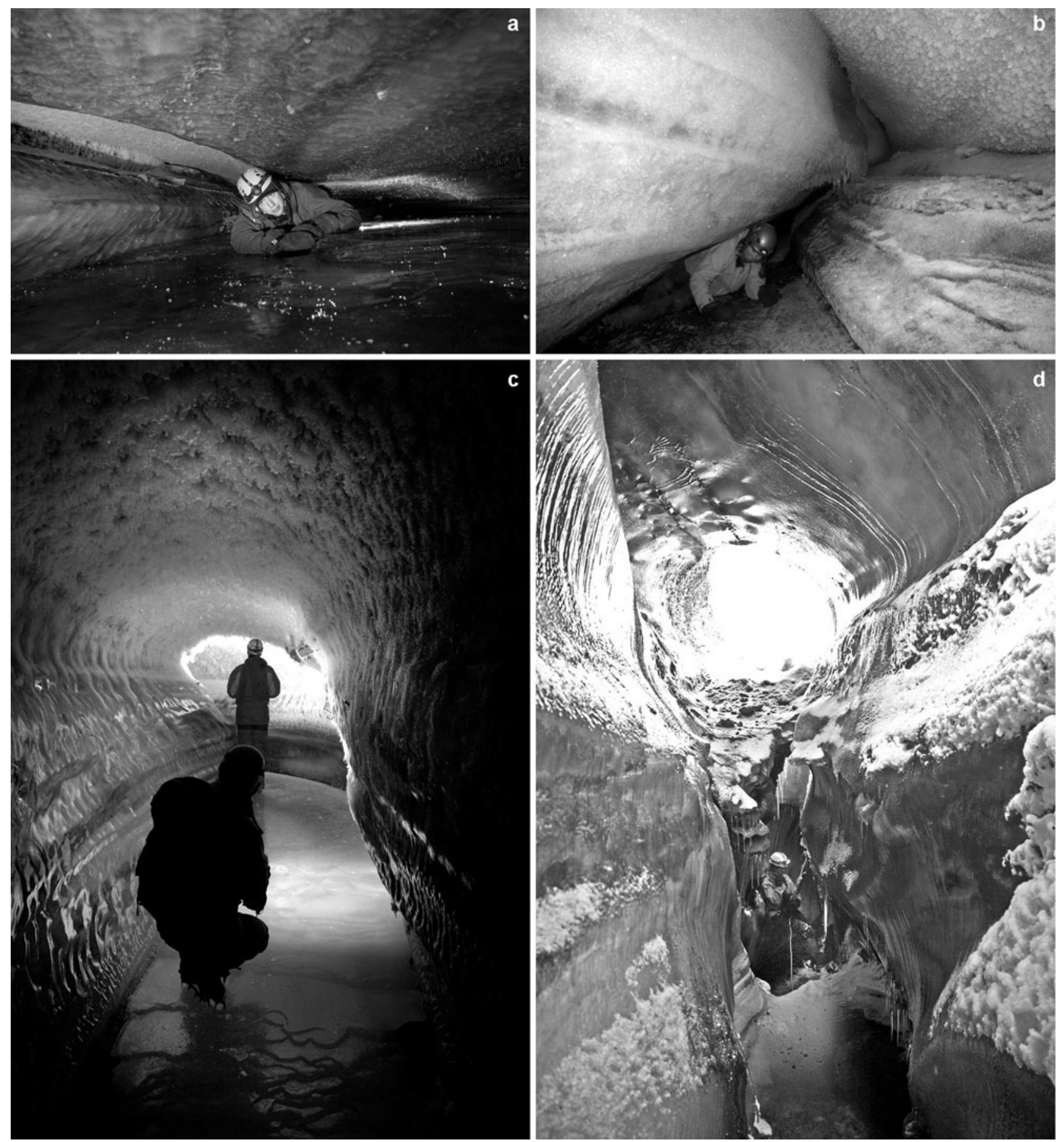

Fig. 5. (a) Canyon suture at A32 (LYR2). (b) The upper reaches of a canyon have been squeezed shut to create this horizontal slot in LYR2, a low, wide passage developed from lateral incision of cutback banks in meander bends. This photograph is an upstream view of the lowerlevel meander cut-off between stations A39 and A50 and is shown as a grey passage outline in Figure 3a. (c) Passage cross-sections between A3 and A7 appear to be a hybrid between phreatic (tube) and vadose (canyon) cross-sectional morphologies and likely represent transient phreatic conditions. (d) In July 2007, the entrance used to access LYR2 was discharging water. Water upwelled via the upper portal shown in this photograph, flowed over the glacier surface for a short distance and discharged to a supraglacial channel.

Cross-sections averaged $10 \mathrm{~m}$ wide and $2-3 \mathrm{~m}$ high and the canyon walls inclined steeply to the right where they terminated in a mass of broken ice blocks and frozen ice breccia. Exploration was halted by rising water in the passage.

\subsection{Supraglacial channel}

The supraglacial channel upstream of $\mathrm{KH} 01 \mathrm{~A}$ is of interest because of the information it can provide concerning the origin of the englacial reaches. The channel is a long-lived feature which is visible on satellite images spanning several years. It originates as a series of rills in a field of penitentes (large cones of ice protruding through very thin debris cover), below the Khumbu icefall known as the Pinnacles, and becomes increasingly entrenched once it enters the more thickly debris-covered part of the glacier, where the channel is typically $5-10 \mathrm{~m}$ deep. The channel exhibits a series of sharp meanders, and in places a combination of lateral channel migration and vertical incision has undercut the cutback banks, creating ice overhangs which are prone to 
collapse. At one meander bend, the channel was bridged by a mass of ice breccia about $25 \mathrm{~m}$ long and 4-5 m wide, composed of sub-rounded to angular ice blocks, rock debris and ice cement (Fig. 9a and b). A gap $\sim 2 \mathrm{~m}$ high existed between the base of the breccia and the channel floor, forming an 'englacial' reach of the stream bed. The breccia appears to have formed when collapsed portions of the cutback bank and farther-traveled ice blocks were rafted into place when discharge in the river was high (i.e. during the summer monsoon), and then jammed in the meander bend. Subsequently, additional ice blocks and rock debris fell onto the ice bridge from the glacier surface above. One such rockfall event was witnessed at close range by the survey team.

\subsection{Interpretation}

The supraglacial channel, KH01A, and KH01B are interpreted as successive stages in a continuous evolutionary sequence. Down-glacier of the pinnacles, stream incision is faster than surface ablation because the ice is insulated by thick layers of debris. Rapid incision and meander migration encourage formation of overhanging cutback banks (Boyd and others, 2004). When discharge is high, floating blocks of ice can jam in tight meander bends and freeze together, forming bridges of frozen ice breccia. Additional debris is added to bridges during meltout and collapse of the overhanging cutback bank, further reducing surface ablation rates over the channel.

$\mathrm{KH} 01 \mathrm{~A}$ is a later stage of the cut-and-fill process. The bands of ice and debris extending along the cave roof and to the glacier surface at both entrances are interpreted as the infill of a canyon incised down from the glacier surface. The former canyon cuts through a topographic high on the glacier, the top of which is $30 \mathrm{~m}$ above the upper entrance. This implies that differential ablation of the debris-covered ice created the current topography after channel initiation and down-cutting. Debris thickness and albedo have long

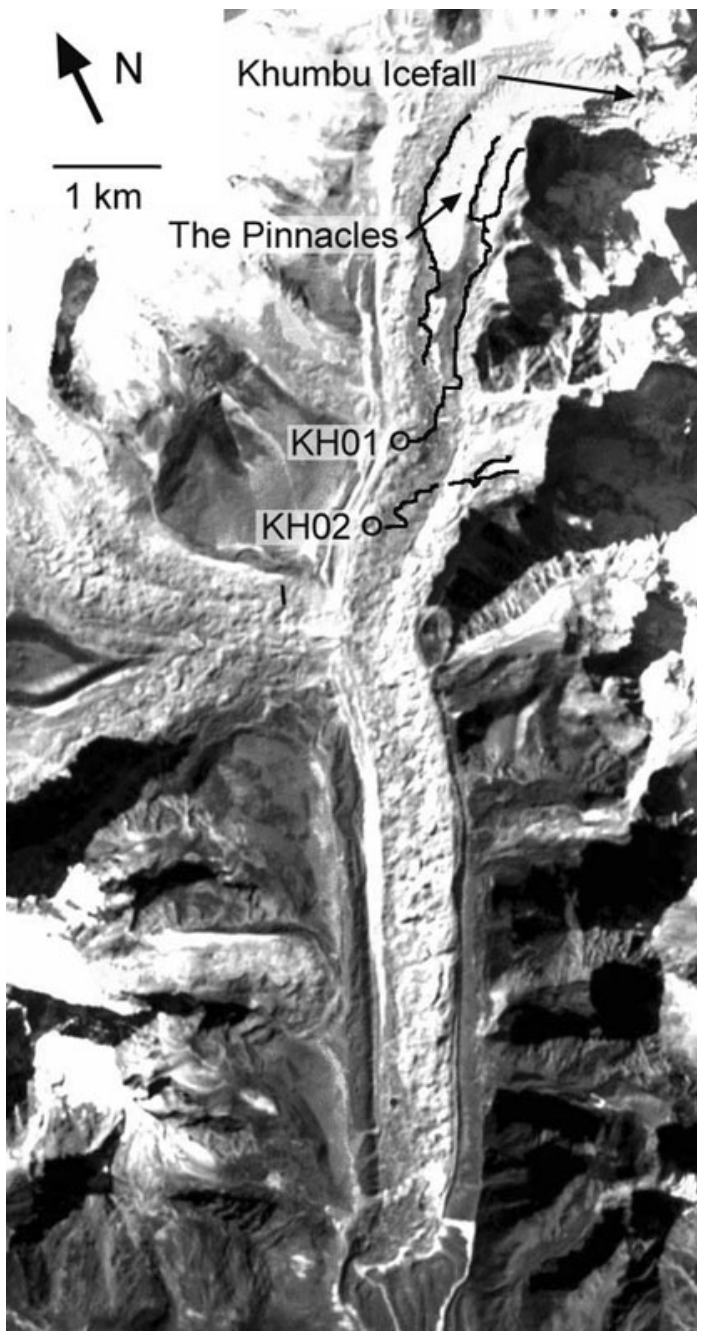

Fig. 6. ASTER (Advanced Spaceborne Thermal and Reflection Radiometer) image of Khumbu Glacier, December 2005, showing locations of cave entrances and supraglacial channels.
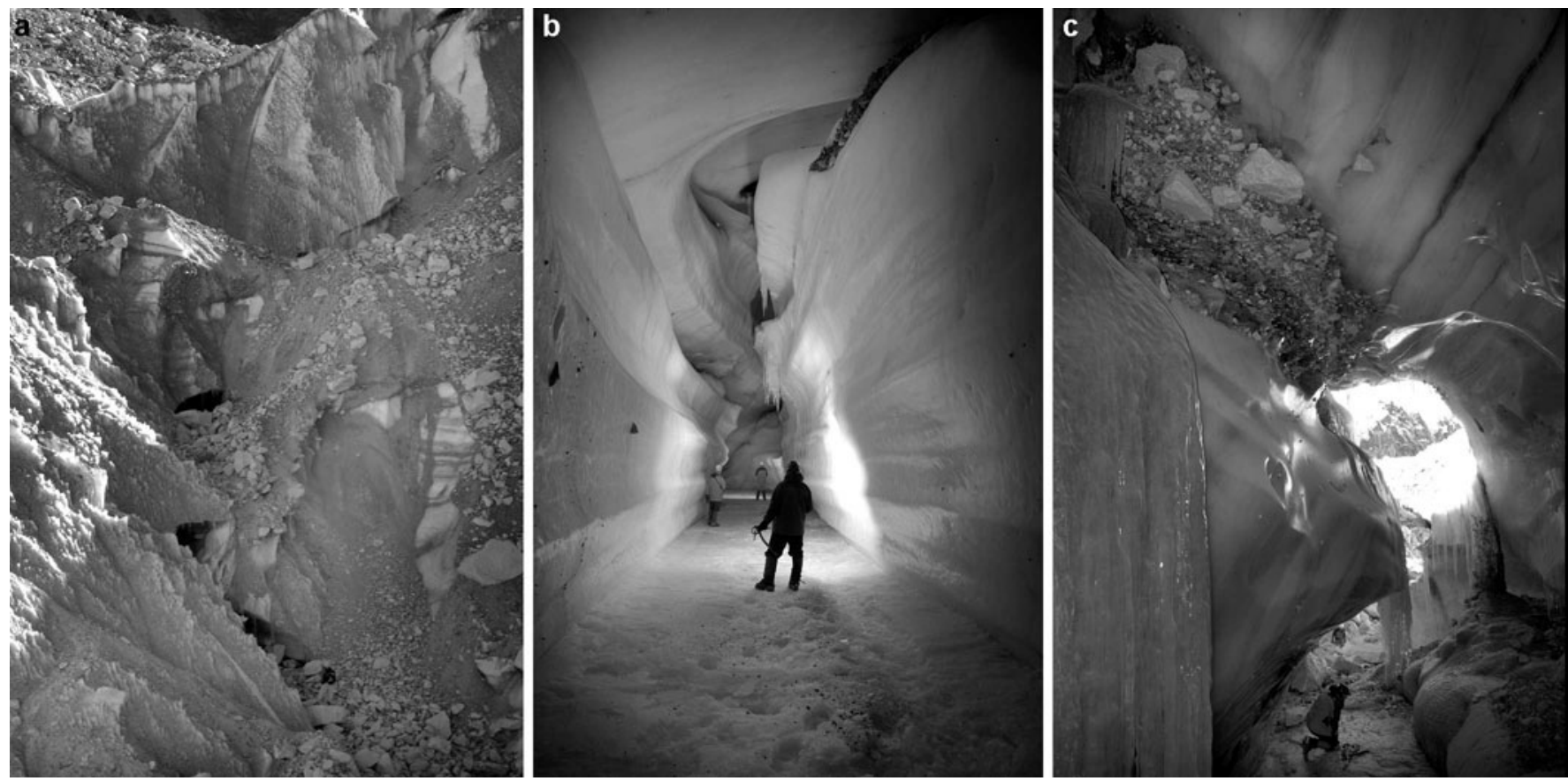

Fig. 7. (a) Lower (northern) entrance to KH01A. (b) The canyon walls of KH01A tapered upward and converged at either a debris band with a dense ice matrix or ice breccias. (c) Debris band near the northern entrance of KH01A. 


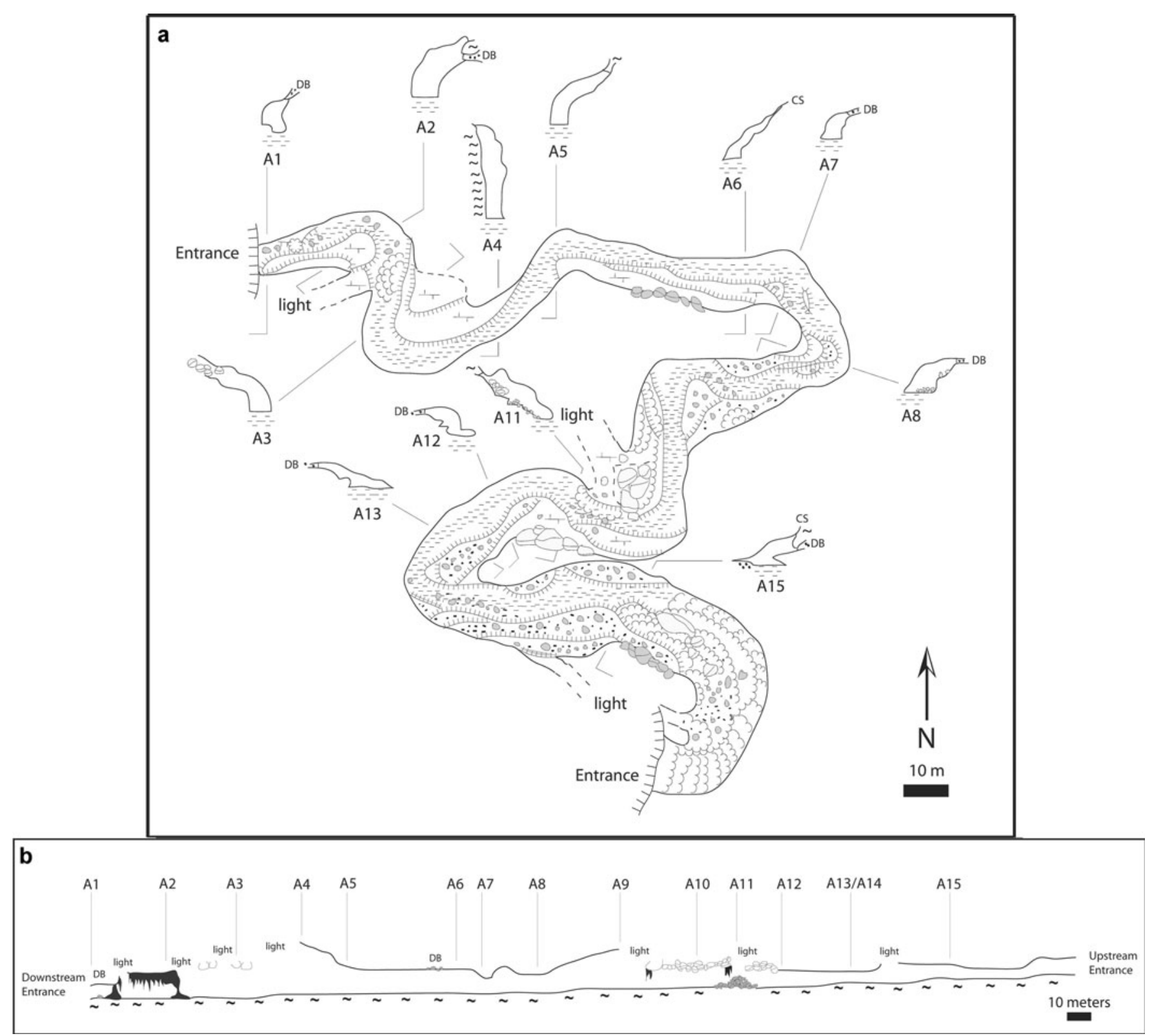

Fig. 8. KH01A, December 2006: (a) plan view; (b) profile along the passage thalweg.
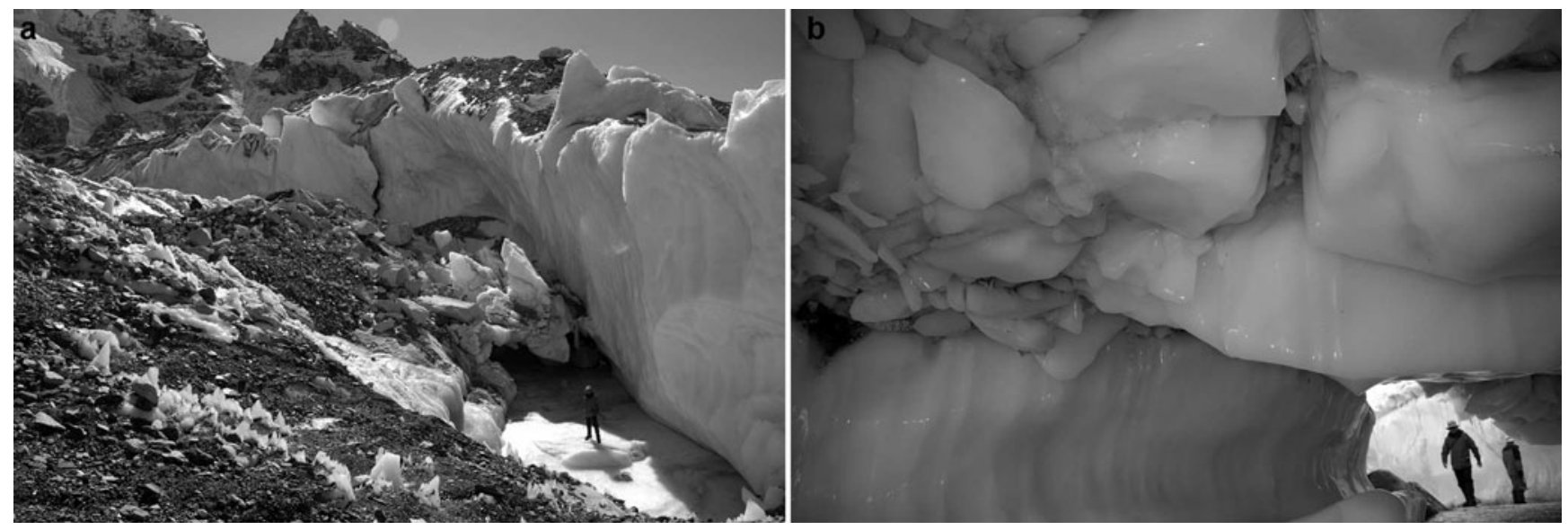

Fig. 9. (a) Upstream of KH01A, ice breccia bridges the supraglacial channel. (b) Ice breccia roof of the 'englacial' reach of the supraglacial channel. 


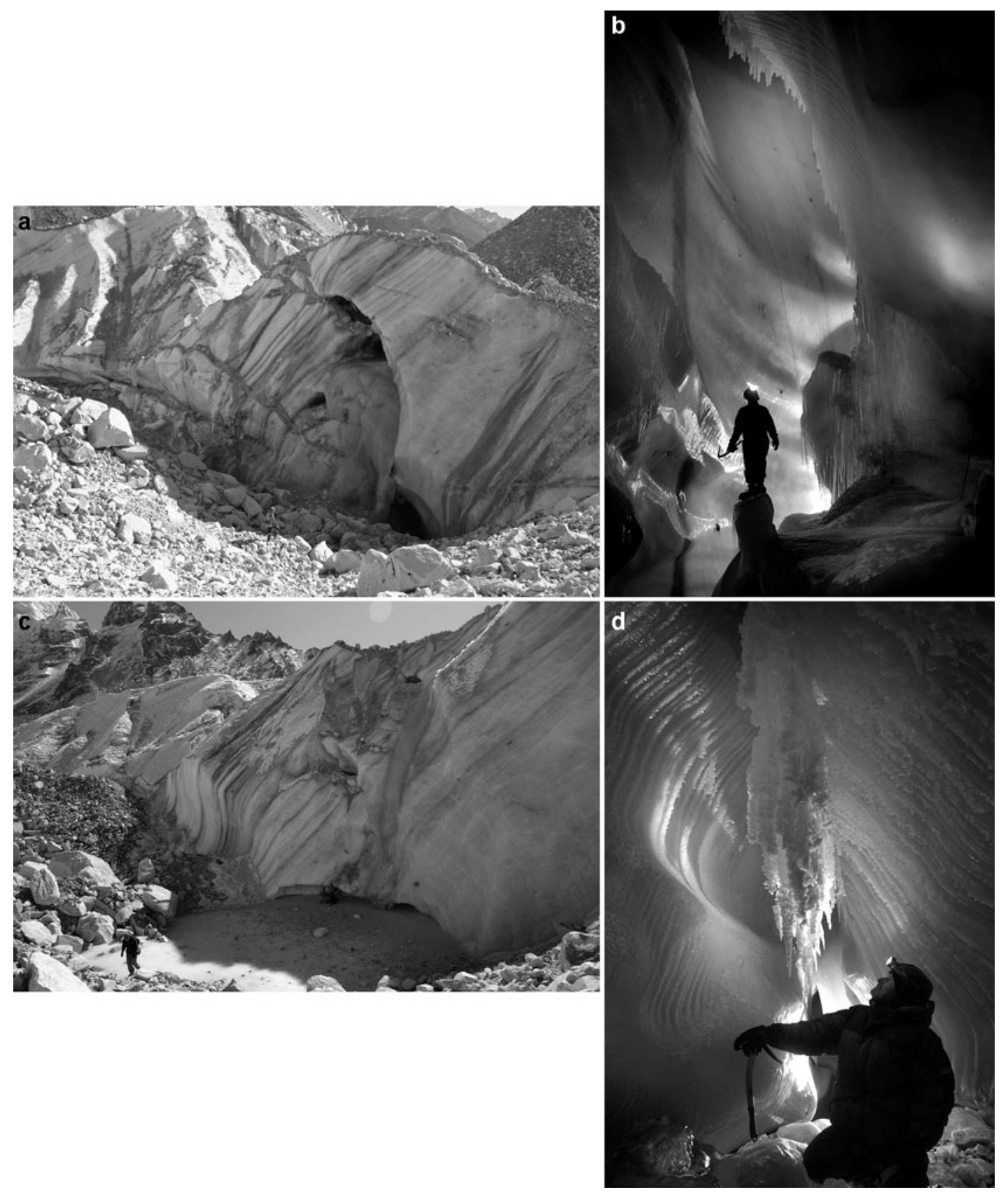

Fig. 10. (a) Entrance of KHO2 in November 2005. Note the debris band and isolated canyon segments partially obscured by waterfall ice. (b) Canyon passage in KHO2 near station A13. (c) The entrance of KH02 in December 2006. The figure in the photo is walking on a frozen lake, beneath which was located the entrance used in 2005. (d) Roof suture in the restricted part of KH02.

been recognized as important controls on the topographic evolution on Khumbu and other Himalayan glaciers (Fushimi and others, 1980; Nicholson and Benn, 2006). Melt-back and collapse of cutback banks concentrates debris over nascent cut-and-closure conduits. This reduces ablation locally and predisposes cut-and-closure canyon apexes to become new topographic highs.

A third stage of passage evolution is found in KH01B. Extensive fills of angular ice blocks reflect widespread collapse of overhanging canyon walls. Long sections of the passage consist of very low horizontal slots, which were being narrowed further by the accumulation of aufeis on the channel floor. It is likely that creep closure is also an important process at this site, since low, wide passages will close more rapidly than circular or vertical-walled ones in response to ice overburden pressure (cf. Hooke and others, 1990).

\subsection{KH02}

This conduit was located at the margin of a large closed depression near the western flank of the glacier, $440 \mathrm{~m}$ south-southwest of KH01 (27 $58^{\prime} 52^{\prime \prime} \mathrm{N}, 86^{\circ} 50^{\prime} 07^{\prime \prime} \mathrm{E}$; $5050 \mathrm{ma.s.l}$.). Three conduit entrances were present at different points along the outcrop of a prominent, dipping debris band (Fig. 10a). A relict incised supraglacial channel extended up-glacier from the lower entrance.

The lowermost passage was surveyed in late November 2005 (Fig. 11). The entrance sloped downwards at $23^{\circ}$ and was partially composed of fallen ice blocks cemented by aufeis. The highest observable parts of the passage tapered upward and met at a partially debris-filled seam in the roof, which could be traced intermittently along the entire length of the passage. Passage dimensions diminished with distance from the entrance, and, at a penetration of $30 \mathrm{~m}$, closed 


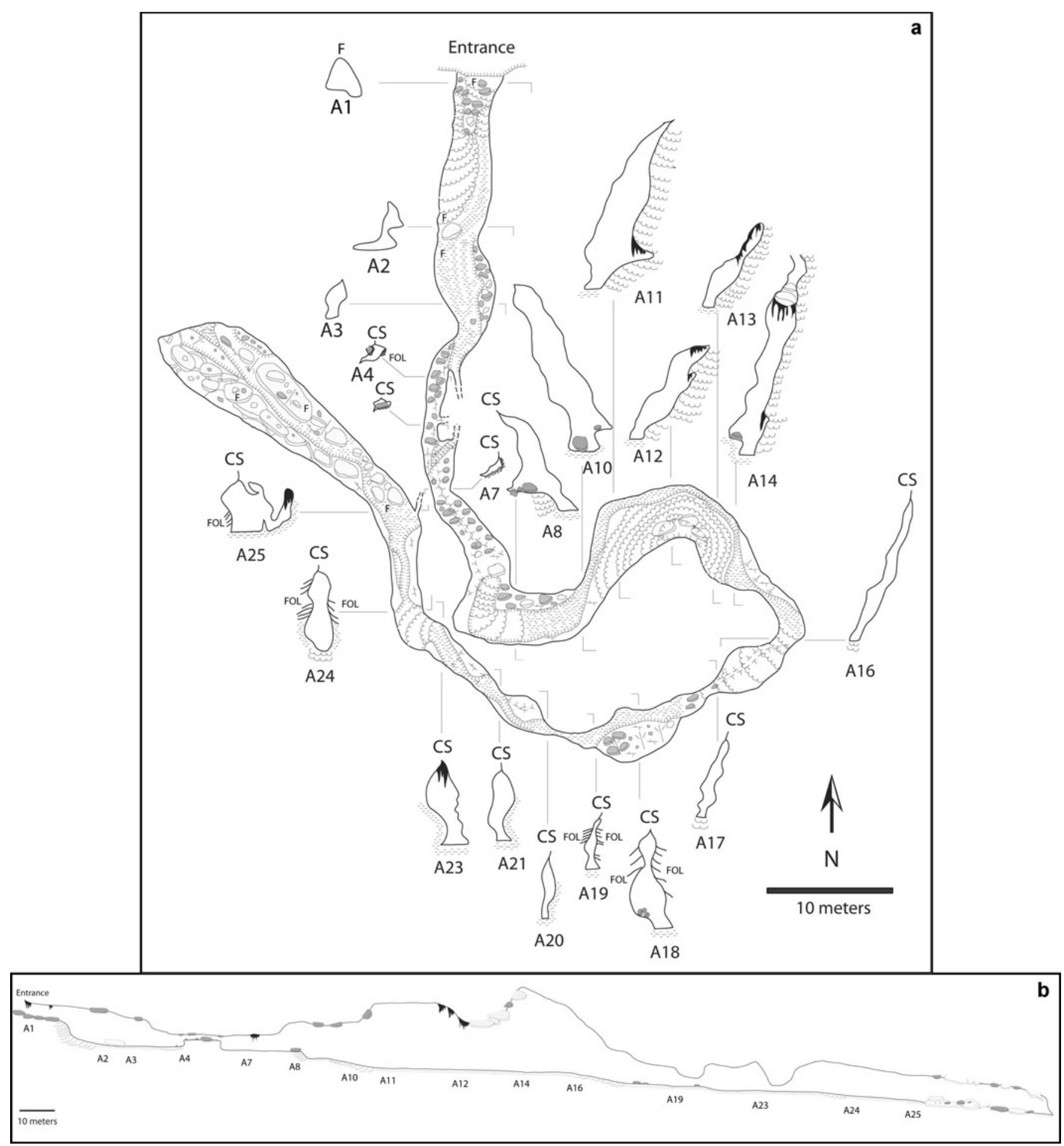

Fig. 11. Plan view (a) and long profile view (b) of $\mathrm{KH} 02$.

down into a tight squeeze $0.4 \mathrm{~m}$ wide and $0.3 \mathrm{~m}$ high (A6); for $24 \mathrm{~m}$ beyond this point, passage dimensions remained very small. Passage morphology in this narrow section consisted of a roughly tubular upper level with a narrow, partially occluded incised slot in the floor. Beyond the narrow section, passage dimensions increased dramatically, opening out into a canyon $18 \mathrm{~m}$ high and $3.5 \mathrm{~m}$ wide (Fig. 10b). In some places, light was visible high above the canyon floor, and extensive covers of aufeis coated the walls below these holes. The canyon was highly sinuous (sinuosity 6.29) and at one point came within $0.5 \mathrm{~m}$ of closing on itself. The canyon floor consistently dropped in elevation, with an average gradient of 0.11 , with lowergradient sections interspersed with a series of frozen waterfalls $0.5 \mathrm{~m}$ high. Passage width showed considerable variation, ranging from 0.5 to $7.0 \mathrm{~m}$. The deepest part of the passage consisted of a room $27 \mathrm{~m}$ long, $4.5 \mathrm{~m}$ wide and $6.5 \mathrm{~m}$ high, which terminated in a frozen-over pool. Fallen ice blocks and coarse rock debris covered the floor. Despite the length of the passage, the innermost end is in close proximity to the entrance.

When revisited in December 2006, KHO2 was inaccessible because the entrance was submerged below a frozen pond (Fig. 10c). From the 2005 survey data, we estimate that 
the volume of stored water (which was at least partially refrozen in December 2006) was $\sim 5300 \mathrm{~m}^{3}$.

\subsection{KH02: interpretation}

$\mathrm{KH} 02$ shares many characteristics with $\mathrm{KH} 01$, and we conclude that it formed in a similar way. The inclined debris band above the entrance and the partially debris-filled seam running along the canyon roof are interpreted as a canyon suture marking the former position of an incising stream channel. Closure was accomplished by a combination of infilling by supraglacial debris and ice breccia and creep closure which isolated the canyon from the glacier surface. Although most of the cave exhibited forms indicative of vadose down-cutting, the narrow section between A4 and A6 (Fig. 11) appears to have experienced a phreatic phase. Because a canyon suture is clearly visible in the roof of the narrow section (Fig 10d), we conclude that this part of the cave underwent epiphreatic modification following an earlier phase of vadose incision and partial closure.

The condition of the cave in 2006 suggests that the system may have reached the end of its evolutionary cycle. It appears likely that the blockage at the lower end of the cave in 2005 did not reopen during the 2006 melt season, and that meltwater filled the cave, flooding it back as far as the entrance. In the following winter season, this accumulated water began to freeze, increasing the integrity of the blockage.

\section{SYNTHESIS AND DISCUSSION}

The evidence from Longyearbreen and Khumbu Glacier allows a generic model of conduit formation by 'cut and closure' to be proposed (Fig. 12).

1. For supraglacial stream channels to evolve into englacial conduits by a process of cut and closure, channel incision must be faster than surface ablation. This occurs where debris cover or low air temperatures inhibit surface melting. The energy driving incision comes from viscous dissipation, so incision rates are directly proportional to discharge and stream slope (Marston, 1983; Fountain and Walder, 1998). Because surface ablation rates must be low, large catchment areas are required to maintain high discharges. Extensive supraglacial drainage networks can only form in largely uncrevassed regions of glaciers, otherwise streams are captured and routed to the subsurface (Stenborg, 1968, 1973; Boon and Sharp, 2003). Conduit sinuosity will be higher on debris-covered glaciers than on clean glaciers for equivalent stream discharges due to sediment transport (Boyd and others, 2004).

2. Channel incision occurs most rapidly by upstream nickpoint migration, which may be an order of magnitude faster than floor down-cutting.

3. Drifting snow or jams of rafted ice blocks initiate closure of the upper reaches of canyons. Partial melting and refreezing or burial by supraglacial debris increases the integrity of the nascent bridges. Snow, debris and aufeis can add to blockages at deeper levels where gaps persist in the canyon roof. Ice breccias initiated by internal collapses (autochthonous breccias) or rafting of nonlocal (allochthonous) blocks can also block deeper parts of englacial canyons.
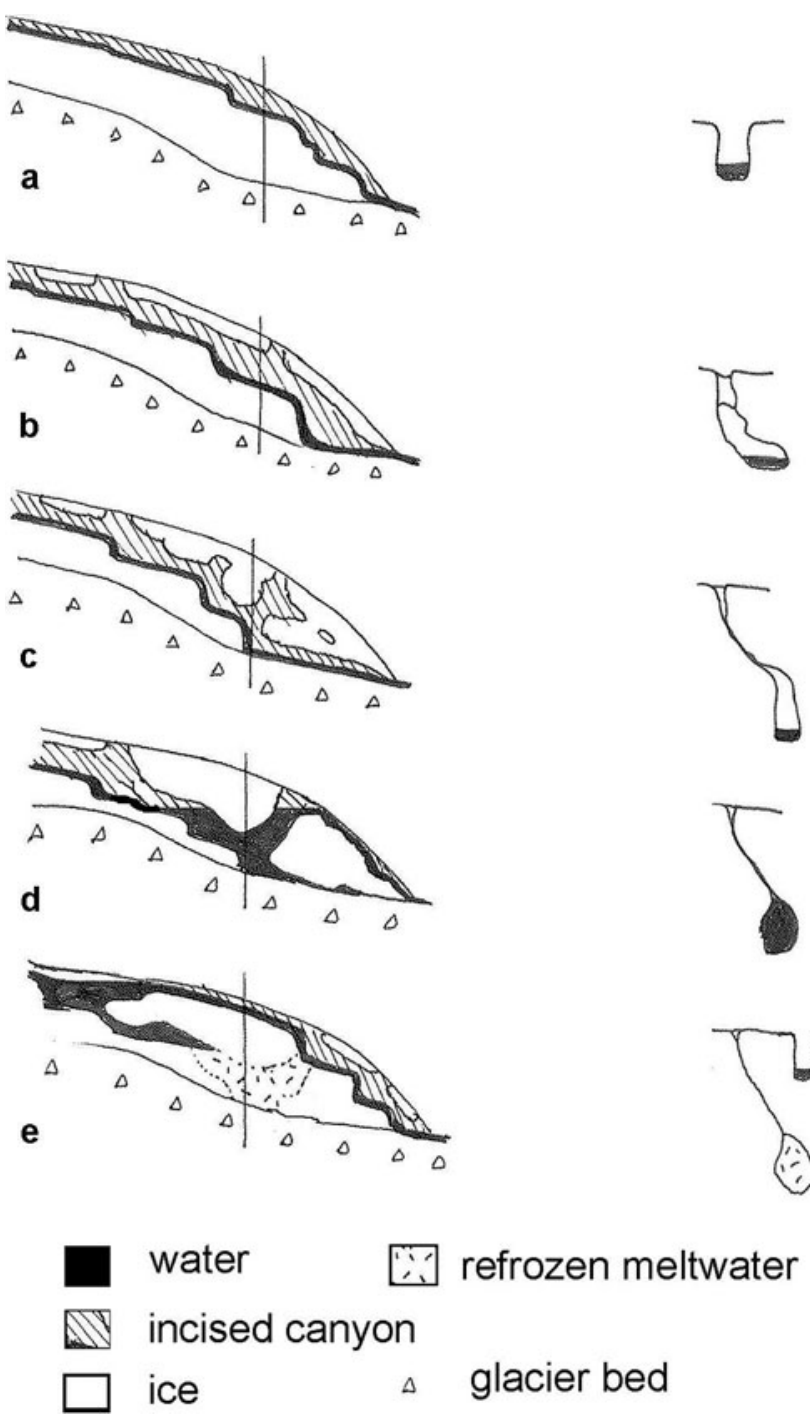

Fig. 12. Conceptual model of conduit development by cut and closure. Left: long profile; right: cross-sections. (a) Conduit begins as a supraglacial stream. (b) If incision is faster than surface ablation, the conduit cuts deeper. Upper reaches of canyons become plugged with snow and aufeis. (c) Continued incision, and closure by aufeis accumulation and ice creep. (d) Lower levels become plugged by aufeis accumulation or creep closure; water backs up to discharge from the next available pre-existing outlet. (e) Winter freezing of ponded water propagates the blockage upstream, and in the following summer water finds the next lowest outlet point. Water flowing onto glacier surface incises new channel.

4. With increasing depth, canyon walls converge by ice creep. Creep closure can also occur in response to horizontal compressive stresses at low overburden pressures. At shallow depths upstream, roof plugs may contain snow, ice or debris infillings and transition to clean canyon sutures at depth downstream.

5. If closure processes reduce passage dimensions to the extent that pipe-full flow occurs at periods of high discharge (epiphreatic conditions), or the passage becomes blocked to back-flood and discharge at a breach in the ceiling, epiphreatic conditions can transform canyons or horizontal slots into tubular morphologies. 
6. Vadose incision terminates at a glacier's hydrological base level, which may be determined by the elevation of impermeable terminal moraines or the lip of an overdeepening.

7. Channel floors can cut down to the glacier bed and form subglacial drainage pathways even beneath cold-based glaciers. Where basal ice is cold, such pathways will not communicate hydrologically with the glacier bed on either side of the channel, and the presence of subglacial water will not influence glacier velocity. In contrast, if cutand-closure conduits reach unfrozen parts of the beds of polythermal glaciers, water could spill out of the conduit through a subglacial film, permeable subglacial sediments or some other form of distributed drainage system.

8. Conduits can become blocked by creep closure at depth or by build-up of secondary ice. Conduit blockages can cause the stream course to be re-routed to higher levels, determined by the elevation of the next possible outlet. If no outlet is available, the conduit will fill completely with water and a new supraglacial diversion channel will develop. Observations over several years in Longyearbreen indicate that conduit down-cutting and upward rerouting is a cyclic process.

Upstream migration of nickpoints can create vertical sinkpoints at the up-glacier end of cut-and-closure conduits, mimicking the morphology of 'tectonic' moulins formed by hydrologically driven overdeepening of crevasses (Stenborg, 1968). Cut-and-closure conduit sinkpoints can be easily distinguished from tectonic moulins when there is no snow cover, by their sinuous canyon sutures extending downglacier (Fig 2a).

We found no evidence that conduits were relict Shrevetype drainage systems inherited from past thermal regimes (Hodgkins, 1997). Inherited Shreve-type conduits would be expected to have multiple tributaries with circular passage cross-sections and plunge steeply to the glacier bed. Instead, we documented long stretches of unbranching, subhorizontal, canyon passages that, for the most part, did not reach the glacier bed. These crucial observations are incompatible with the predictions of 'classical' englacial drainage theory. The documented long stretches of horizontal passage additionally contradict the Stuart and others (2003) hypothesis that conduits in cold ice are relict drainage features inherited from a former thermal regime.

The observations presented in this paper confirm that englacial conduits can develop by the incision and closure of supraglacial streams, as proposed by Fountain and Walder (1998) and Vatne (2001). However, our results show that the conditions required for conduit initiation, the mechanisms of closure, and the ways in which conduits evolve through time, differ in several respects from previous models and thus constrain their occurrence to predictable locations.

First, the primary condition for conduit initiation and survival is that incision rates exceed glacier surface ablation rates, and pre-existing crevasses are not required to initiate conduit formation. In the Fountain and Walder model, incising conduits are given a 'head start' by initiating at the bottom of a crevasse. However, such a conduit will only persist if incision rates outpace surface ablation, so a preexisting crevasse is neither a necessary nor sufficient condition for conduit inception. Moreover, while small discharges are unlikely to generate sufficiently large incision rates, large discharges into crevasses might be expected to encourage deep fracture propagation, routing meltwater vertically towards the bed (Boon and Sharp, 2003; Alley and others, 2005; Van der Veen, 2007; Catania and others, 2008). Although shallow or relict crevasses can guide surface drainage patterns (Marston, 1983), crevasses are not expected to be important as nucleation sites for cut-and-closure englacial conduits. Indeed, conduits of this type are much more likely to form on uncrevassed parts of glaciers, due to the requirements that stream contributing areas are large and that discharge is not diverted vertically through fractures.

Second, in all the examples we have studied, accumulation of snow or ice has played a major role in roof closure, and ice creep became important only in later stages of conduit development. Like incision rates, roof blockage processes also appear to be climatically controlled. Snow and ice bridges are most likely to survive the following melt season if surface ablation rates are small. Additionally, effective bridging will only occur where canyons are narrow. Where melt-season temperatures are high, supraglacial channels tend to have high width-to-depth ratios due to melt-back of the channel walls. Wide channel reaches will discourage the formation of ice jams and snow bridges, and their survival through subsequent years. Thus, even where supraglacial stream discharges are large enough to cut deep canyons, cut-and-closure type conduits are unlikely to form.

Third, conduits will not necessarily incise monotonically towards the bed, and drainage can be re-routed to higher levels within the glacier following the blockage of deeper passages. Major blockages occur where closure processes outpace enlargement processes, and may occur in response to roof collapses, creep closure, or freezing of stored water. Because the chance of winter-season blockage increases with depth, we expect that perennial cut-and-closure conduits are unlikely to persist below thick ice. There is evidence on Longyearbreen for multiple episodes of downward incision, conduit blockage and upward re-routing. Incision from the surface to the bed takes many years, whereas upward re-routing to the surface can be accomplished in a single season; at this locality, therefore, cut-andclosure conduits will be located at the bed for a relatively small proportion of their life cycle.

Observations elsewhere in Svalbard indicate that cut-andclosure conduits are very widespread. We and other researchers have observed over 20 such conduits on 14 glaciers (personal communication from A. Hormes, 2008) and we conclude that cut and closure is the dominant process for forming low-gradient englacial conduits on uncrevassed regions of polythermal glaciers.

These findings establish important constraints for models of polythermal glaciers and the Greenland ice sheet. If, as we suggest, cut-and-closure conduits are the only conduits likely to form in unstressed cold ice, they are unlikely to have any influence on the dynamic response of the Greenland ice sheet. Conduits will incise to an ice depth sufficient to close conduits in the winter when recharge is absent. The conduit will either become re-established at a higher elevation or, if no other outlet is available, be abandoned. In either case, the conduit will be unlikely to reach the bed in thick ice. In thin ice, cut-and-closure conduit formation is too slow to explain seasonal velocity transients at the onset of the melt season on land-terminating glaciers (Copland and others, 2003). Because cut-and-closure conduits cannot incise below base level, they cannot reach the bed of tidewater glaciers and 
should not cause their observed seasonal speed-ups (Vieli and others, 2004).

We conclude that the only viable hypothesis for surface melt to access glacier beds through thick ice is hydrologically driven overdeepening of crevasses (e.g. Alley and others, 2005; Van der Veen, 2007), which requires large discharges of water and stressed ice. Applied to the Greenland ice sheet, this means that rapid subglacial recharge is most likely to occur in areas of accelerating flow.

\section{ACKNOWLEDGEMENTS}

Fieldwork was funded by the US National Geographic Society, the US National Speleological Society, the Explorers Club, the Royal Geographical Society, the Royal Scottish Geographical Society, the Mount Everest Foundation, the American Alpine Club, the Carnegie Trust for Universities of Scotland, SportRaxx by Simpson, The University Centre in Svalbard, Sigma Chi, the Evolving Earth Foundation and the University of Florida. We thank E. Gjermundsen, S. Keene, L. Nicholson and P. Sherpa for field assistance. Helpful reviews by A. Fountain, A. Hodson and G. Vatne are gratefully acknowledged.

\section{REFERENCES}

Alley, R.B., T.K. Dupont, B.R. Parizek and S. Anandakrishnan. 2005. Access of surface meltwater to beds of sub-freezing glaciers: preliminary insights. Ann. Glaciol., 40, 8-14.

Arcone, S.A. and N.E. Yankielun. 2000. 1.4 GHz radar penetration and evidence of drainage structures in temperate ice: Black Rapids Glacier, Alaska, U.S.A. J. Glaciol., 46(154), 477-490.

Blatter, H. and K. Hutter. 1991. Polythermal conditions in Arctic glaciers. J. Glaciol., 37(126), 261-269.

Boon, S. and M. Sharp. 2003. The role of hydrologically-driven ice fracture in drainage system evolution on an Arctic glacier. Geophys. Res. Lett., 30(18), 1916. (10.1029/2003GL018034.)

Boyd, B., S.L. Goetz and N.R. Ham. 2004. Supraglacial stream incision into debris-covered ice, Matanuska Glacier, AK. Geol. Soc. Am. Abstr., 36(3), 11.

Catania, G.A., T.A. Neumann and S.F. Price. 2008. Characterizing englacial drainage in the ablation zone of the Greenland ice sheet. J. Glaciol., 54(187), 567-578.

Copland, L., M.J. Sharp and P.W. Nienow. 2003. Links between short-term velocity variations and the subglacial hydrology of a predominantly cold polythermal glacier. J. Glaciol., 49(166), 337-348.

Dasher, G.R. 1997. On station. Huntsville, AL, National Speleological Society.

Etzelmüller, B., R.S. Ödegård, G. Vatne, R.S. Mysterud, T. Tonning and J.L. Sollid. 2000. Glacier characteristics and sediment transfer system of Longyearbreen and Larsbreen, western Spitsbergen. Nor. Geogr. Tidsskr., 54(4), 157-168.

Ford, D.C. and P.W. Williams. 1989. Perspectives in karst hydrogeology and cavern genesis. London, Unwin Hyman Academic.

Fountain, A.G. and J.S. Walder. 1998. Water flow through temperate glaciers. Rev. Geophys., 36(3), 299-328.

Fountain, A.G., R.W. Jacobel, R. Schlichting and P. Jansson. 2005. Fractures as the main pathways of water flow in temperate glaciers. Nature, 433(7026), 618-621.

Fushimi, H., M. Yoshida, O. Watanabe and B.P. Upadhyay. 1980. Distributions and grain sizes of supraglacial debris in the Khumbu glacier, Khumbu region, Nepal. Seppyo, J. Jpn. Soc. Snow Ice, 41, Special Issue, 18-25.

Gulley, J. and D.I. Benn. 2007. Structural control of englacial drainage systems in Himalayan debris-covered glaciers. J. Glaciol., 53(182), 399-412.
Hagen, J.O., K. Melvold, F. Pinglot and J.A. Dowdeswell. 2003. On the net mass balance of the glaciers and ice caps in Svalbard, Norwegian Arctic. Arct. Antarct. Alp. Res., 35(2), 264-270.

Hansen, O.H. 2001. Internal drainage of some subpolar glaciers on Svalbard. (MSc thesis, University of Bergen.)

Hodgkins, R. 1997. Glacier hydrology in Svalbard, Norwegian High Arctic. Quat. Sci. Rev., 16(9), 957-973.

Holmlund, P. 1988. Internal geometry and evolution of moulins, Storglaciären, Sweden. J. Glaciol., 34(117), 242-248.

Hooke, R.LeB., T. Laumann and J. Kohler. 1990. Subglacial water pressures and the shape of subglacial conduits. J. Glaciol., 36(122), 67-71.

Humlum, O., B. Elberling, A. Hormes, K. Fjordheim, O.H. Hansen and J. Heinemeier. 2005. Late-Holocene glacier growth in Svalbard, documented by subglacial relict vegetation and living soil microbes. Holocene, 15(3), 396-407.

Iwata, S., O. Watanabe and H. Fushimi. 1980. Surface morphology in the ablation area of the Khumbu glacier. Seppyo, J. Jpn. Soc. Snow Ice, 41, Special Issue, 9-17.

Knighton, A.D. 1985. Channel form adjustment in supraglacial streams, Austre Okstindbreen, Norway. Arct. Antarct. Alp. Res., 17(4), 451-466.

Kodama, H. and S. Mae. 1976. Flow of glaciers in the Khumbu region. Seppyo, J. Jpn. Soc. Snow Ice, 38, Special Issue, Part 1, 31-36.

Mae, S. 1976. Ice temperature of Khumbu Glacier. Seppyo, J. Jpn. Soc. Snow Ice, 38, Special Issue, 37-38.

Marston, R.A. 1983. Supraglacial stream dynamics on the Juneau Icefield. Ann. Assoc. Am. Geogr., 73(4), 597-608.

Müller, D. 2007. Incision and closure processes of meltwater channels on the glacier Longyearbreen, Spitsbergen. (MSc thesis, Technische Universität Braunschweig and The University Centre in Svalbard.)

Nakawo, M., H. Yabuki and A. Sakai. 1999. Characteristics of Khumbu Glacier, Nepal Himalaya: recent changes in the debriscovered area. Ann. Glaciol., 28, 118-122.

Neumann, U. 2006. Climate-glacier links on Brøggerbreen, Svalbard. (MSc thesis, University of Oslo.)

Nicholson, L. and D.I. Benn. 2006. Calculating ice melt beneath a debris layer using meteorological data. J. Glaciol., 52(178), 463-470.

Palmer, A.N. 2002. Speleogenesis in carbonate rocks. In Gabrovšek, F., ed. Evolution of karst: from prekarst to cessation. Postojna-Ljubljana, Zalozba ZRC, 43-60.

Piccini, L., A. Romeo and G. Badino. 2000. Moulins and marginal contact caves in the Gornergletscher, Switzerland. Nimbus 23-24, 94-99.

Pulina, M. 1984. Glacierkarst phenomena in Spitsbergen. Nor. Geogr. Tidsskr., 38(3-4), 163-168.

Pulina, M. and J. Rehák. 1991. Glacial caves in Spitsbergen. In Eraso, A., ed. 1st International Symposium of Glacier Caves and Karst in Polar Regions, 1-5 October 1990, Madrid, Spain. Proceedings. Madrid, International Working Group on Glacier Caves and Karst in Polar Regions, 93-117.

Robin, G.de Q. 1974. Correspondence. Depth of water-filled crevasses that are closely spaced. J. Glaciol., 13(69), 543.

Röthlisberger, H. and H. Lang. 1987. Glacial hydrology. In Gurnell, A.M. and M.J. Clark, eds. Glacio-fluvial sediment transfer: an alpine perspective. Chichester, etc., Wiley, 207-284.

Seko, K., H. Yabuki, M. Nakawo, A. Sakai, T. Kadota and Y. Yamada. 1998. Changing surface features of Khumbu Glacier, Nepal Himalayas revealed by SPOT images. Bull. Glacier Res. 16, 33-41.

Shreve, R.L. 1972. Movement of water in glaciers. J. Glaciol., 11(62), 205-214.

Stenborg, T. 1968. Glacier drainage connected with ice structures. Geogr. Ann., 50A(1), 25-53.

Stenborg, T. 1973. Some viewpoints on the internal drainage of glaciers. IASH Publ. 95 (Symposium at Cambridge 1969 Hydrology of Glaciers), 117-129. 
Stuart, G., T. Murray, N. Gamble, K. Hayes and A. Hodson. 2003. Characterization of englacial channels by groundpenetrating radar: an example from Austre Brøggerbreen, Svalbard. J. Geophys. Res., 108(B11), 2525. (10.1029/ 2003JB002435.)

Van der Veen, C.J. 2007. Fracture propagation as means of rapidly transferring surface meltwater to the base of glaciers. Geophys. Res. Lett., 34(1), L01501. (10.1029/2006GL028385.)

Vatne, G. 2001. Geometry of englacial water conduits, Austre Brøggerbreen, Svalbard. Nor. Geogr. Tidsskr., 55(2), 85-93.

Vatne, G. and I. Refsnes. 2003. Channel pattern and geometry of englacial conduits. In Eraso, A. and C. Dominguez, eds. 6th
International Symposium on Glacier Caves and Karst in Polar Regions, 3-8 September 2003, Ny-Ålesund, Svalbard, Norway. Proceedings. Madrid, International Commission on Glacier Caves and Karst in Polar Regions, 181-188.

Vieli, A., J. Jania, H. Blatter and M. Funk. 2004. Short-term velocity variations on Hansbreen, a tidewater glacier in Spitsbergen. J. Glaciol., 50(170), 389-398.

White, W.B. 1988. Geomorphology and hydrology of karst terrains. New York, etc., Oxford University Press.

Zwally, H.J., W. Abdalati, T. Herring, K. Larson, J. Saba and K. Steffen. 2002. Surface melt-induced acceleration of Greenland ice-sheet flow. Science, 297(5579), 218-222.

MS received 7 April 2008 and accepted in revised form 24 August 2008 